\title{
Hedgehog Signaling
}

\section{Philip W. Ingham}

Institute of Molecular and Cell Biology, Singapore 138673

Correspondence: pingham@imcb.a-star.edu.sg

The Hedgehog (Hh) proteins belong to one of a small number of families of secreted signals that play a central role in the development of most metazoans. hh itself was originally identified as a mutation that causes a "segment polarity" phenotype in Drosophila - as were most of the core components of the Hh signal transduction pathway (Ingham et al. 2011). These components have been highly conserved between flies and vertebrates (Figs. 1 and 2); however, mammals express three related proteins, Sonic hedgehog (Shh), Indian hedgehog, and Desert hedgehog (Dhh), and genetic analysis in mice has uncovered a vertebrate-specific role of the primary cilium in Hh signaling (Goetz et al. 2009).

An unusual feature of Hh proteins is their covalent coupling to cholesterol, which occurs during autocleavage of the proprotein to yield the signaling moiety, $\mathrm{HhN}$ (Beachy et al. 1997). HhN is also palmitoylated at its amino terminus by an acyl transferase encoded by the Drosophila skinny hedgehog gene (Skn). Secretion of lipidated $\mathrm{HhN}$ requires the function of a large multipass transmembrane protein, Dispatched, that is structurally related to the Hh receptor Patched (Ptch1) (Ingham et al. 2011). Binding of HhN to Ptcl is promoted by two other transmembrane proteins, CDO and BOC (known as IHOG and BOI in Drosophila), which act redundantly to bind $\mathrm{HhN}$ via one of several fibronectin III (FnIII) motifs in their extracellular domains (Beachy et al. 2010). In its unbound state, Ptc1 localizes to the primary cilium (Rohatgi and Scott 2007), where it acts via a poorly characterized mechanism, thought to involve the transport of one or more lipids, to suppress the activity of the G-protein-coupled receptor (GPCR)-like protein Smoothened (Smo) (Ayers and Thérond 2010).

The principal response of cells to $\mathrm{HhN}$ is the activation of target genes by the Gli zinc finger proteins. Gli2 and Gli3 (but not Gli1) are bifunctional transcription factors: their full-length forms function as transcriptional activators, but they can be converted into lower-molecular-weight transcriptional repressors. This is promoted by the phosphorylation of a series of motifs within the carboxy-terminal domain of the protein. These motifs are sequentially phosphorylated by PKA, GSK3, and CKI to generate recognition signals for the F-box protein $\mathrm{bTrCP}$, a component of the SCF complex. This in turn catalyzes the ubiquitylation of the carboxyl terminus, targeting it for degradation by the proteasome to yield the truncated amino-terminal repressor forms, Gli2/3R (Ingham et al. 2011). These bind to $\mathrm{Hh}$ target genes to repress their transcription. Gli2/3 proteins appear to shuttle up and down the primary cilium in association with the Cos/Kif7 and SuFu proteins; in the absence of Smo activity, this association seems to promote their processing at the base of the primary cilium. Inactivation of Ptc by HhN results in Smo being transported to the tip of the primary cilium (a process that requires Kif3a and $\beta$-arrestin activity), where its activity promotes the dissociation of the Gli2/3-Cos-SuFu complex (Tukachinsky et al. 2010), releasing the full-length highly labile forms

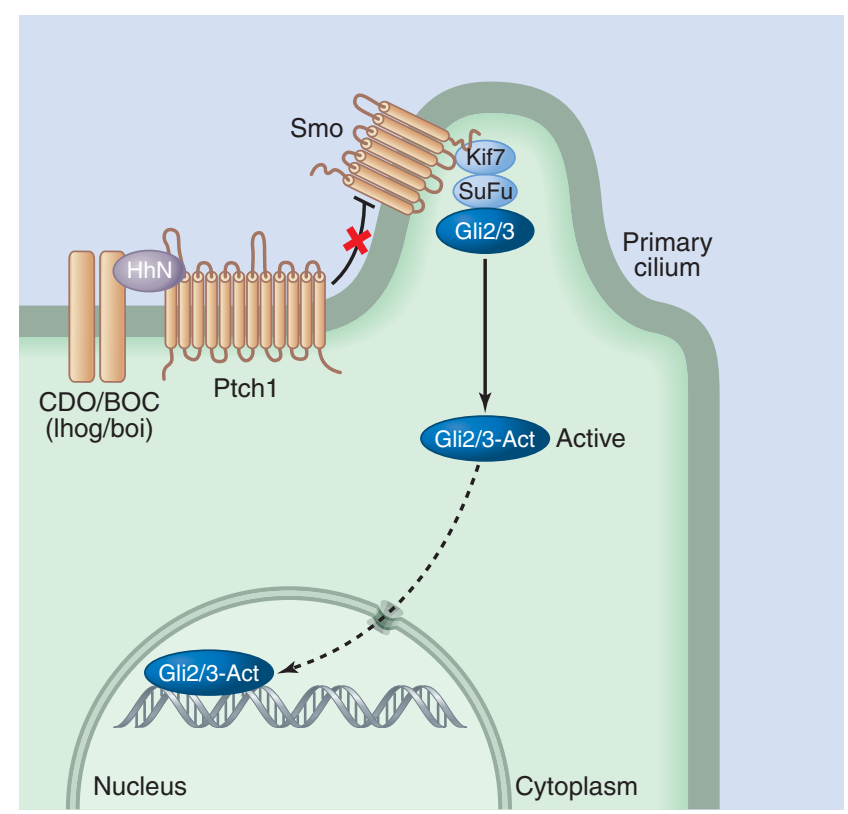

Figure 1. Hedgehog signaling (simplified view).

Editors: Lewis Cantley, Tony Hunter, Richard Sever, and Jeremy Thorner

Additional Perspectives on Signal Transduction available at www.cshperspectives.org

Copyright $\odot 2012$ Cold Spring Harbor Laboratory Press; all rights reserved; doi: 10.1101/cshperspect.a011221 
P.W. Ingham

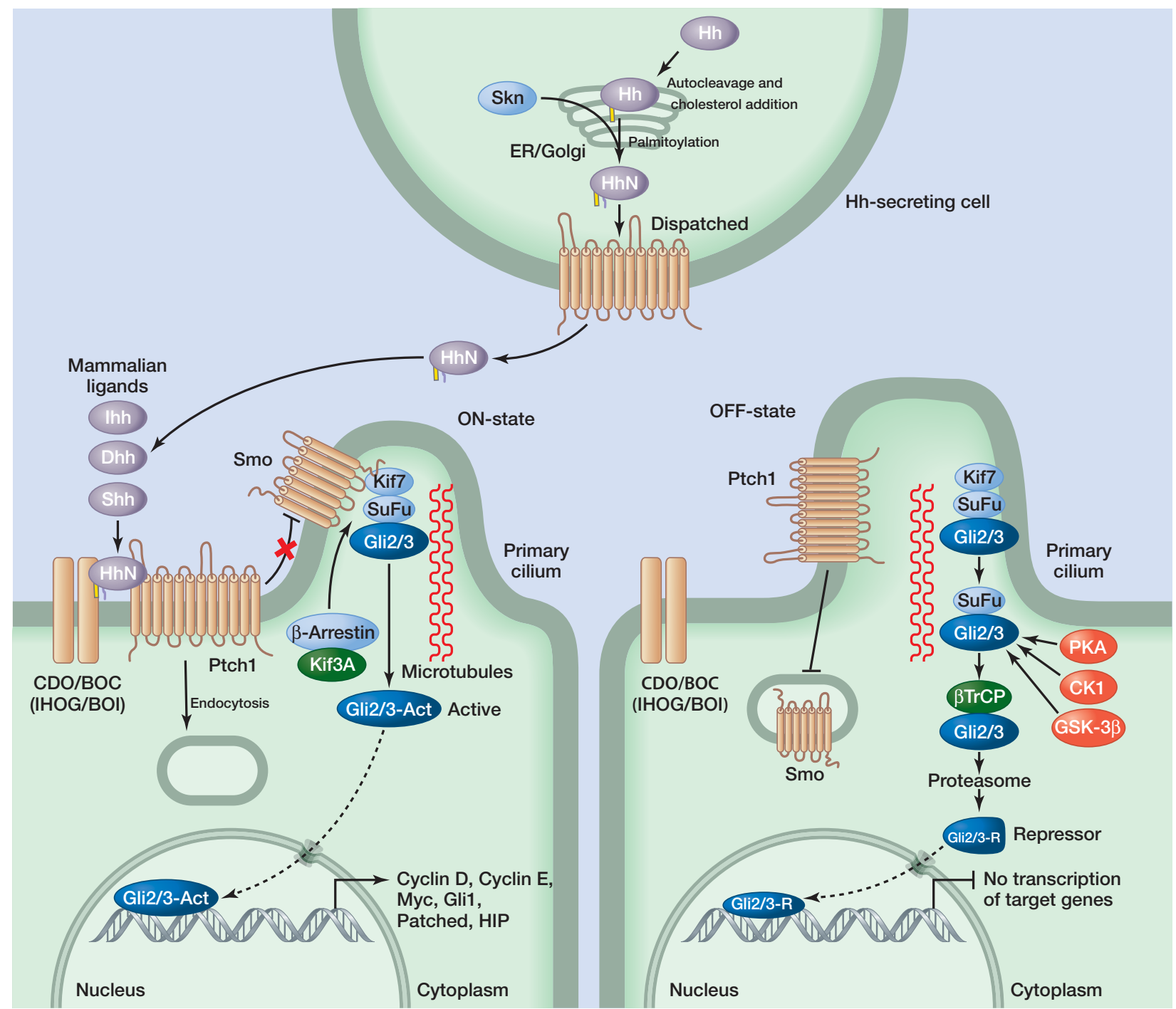

Figure 2. Hedgehog signaling.

of the Gli proteins. These translocate to the nucleus and activate transcription of target genes, such as Ptch1, which attenuates the signal, Gli1, which amplifies the signal, and the genes encoding the cell cycle regulators, Myc, cyclin $\mathrm{D}$, and $\mathrm{E}$.

Figures 1 and 2 adapted, with permission, from Cell Signaling Technology (http://www.cellsignal.com).

\section{REFERENCES}

Ayers KL, Thérond PP. 2010. Evaluating smoothened as a G-protein-coupled receptor for Hedgehog signalling. Trends Cell Biol 20: $287-298$
Beachy PA, Cooper MK, Young KE, von Kessler DP, Park WJ, Hall TM, Leahy DJ, Porter JA. 1997. Multiple roles of cholesterol in hedgehog protein biogenesis and signaling. Cold Spring Harb Symp Quant Biol 62: 191-204.

Beachy PA, Hymowitz SG, Lazarus RA, Leahy DJ, Siebold C. 2010. Interactions between Hedgehog proteins and their binding partners come into view. Genes Dev 24: 2001-2012.

Goetz SC, Ocbina PJ, Anderson KV. 2009. The primary cilium as a Hedgehog signal transduction machine. Methods Cell Biol 94: 199222.

Ingham PW, Nakano Y, Seger C. 2011. Mechanisms and functions of Hedgehog signalling across the metazoa. Nat Rev Genet 12: 393-406.

Rohatgi R, Scott MP. 2007. Patching the gaps in Hedgehog signalling. Nat Cell Biol 9: 1005-1009.

Tukachinsky H, Lopez LV, Salic A. 2010. A mechanism for vertebrate Hedgehog signaling: Recruitment to cilia and dissociation of $\mathrm{SuFu}-\mathrm{Gli}$ protein complexes. J Cell Biol 191: 415-428. 


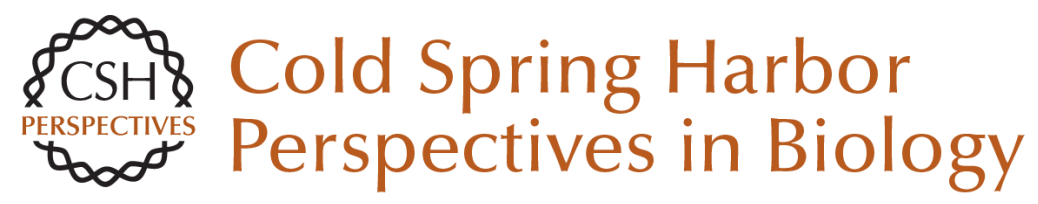

\section{Hedgehog Signaling}

Philip W. Ingham

Cold Spring Harb Perspect Biol 2012; doi: 10.1101/cshperspect.a011221

Subject Collection Signal Transduction

Cell Signaling and Stress Responses Gökhan S. Hotamisligil and Roger J. Davis

Protein Regulation in Signal Transduction Michael J. Lee and Michael B. Yaffe

Synaptic Signaling in Learning and Memory Mary B. Kennedy

Vertebrate Reproduction Sally Kornbluth and Rafael Fissore

Signaling in Lymphocyte Activation Doreen Cantrell

Signaling in Muscle Contraction Ivana Y. Kuo and Barbara E. Ehrlich

Toll-Like Receptor Signaling Kian-Huat Lim and Louis M. Staudt

Signaling Pathways that Regulate Cell Division Nicholas Rhind and Paul Russell
Second Messengers

Alexandra C. Newton, Martin D. Bootman and John D. Scott

Signals and Receptors Carl-Henrik Heldin, Benson Lu, Ron Evans, et al.

Cell Death Signaling Douglas R. Green and Fabien Llambi

Signaling Networks that Regulate Cell Migration Peter Devreotes and Alan Rick Horwitz

Signaling Networks: Information Flow, Computation, and Decision Making Evren U. Azeloglu and Ravi lyengar

Signal Transduction: From the Atomic Age to the Post-Genomic Era Jeremy Thorner, Tony Hunter, Lewis C. Cantley, et al.

Signaling by the TGF $\beta$ Superfamily Jeffrey L. Wrana

Subversion of Cell Signaling by Pathogens Neal M. Alto and Kim Orth

For additional articles in this collection, see http://cshperspectives.cshlp.org/cgi/collection/

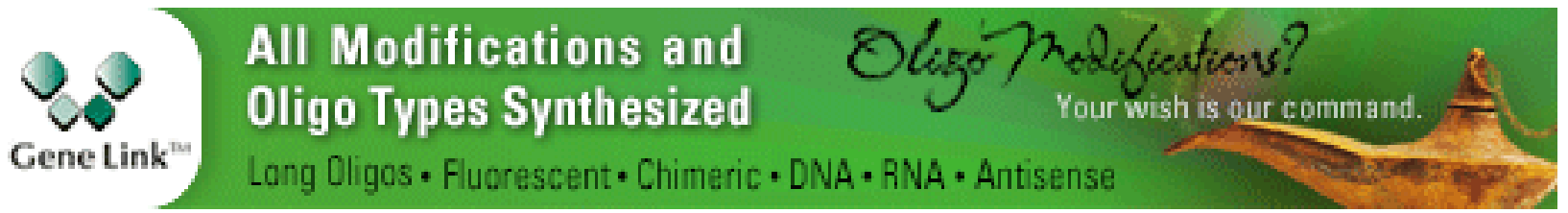

Copyright @ 2012 Cold Spring Harbor Laboratory Press; all rights reserved 